Article

\title{
Investigation and Improvement of Scalable Oxygen Reducing Cathodes for Microbial Fuel Cells by Spray Coating
}

\author{
Thorben Muddemann ${ }^{1, *,+}$, Dennis Haupt ${ }^{2, \dagger}$, Bolong Jiang ${ }^{1}$, Michael Sievers ${ }^{2}(\mathbb{D}$ and \\ Ulrich Kunz ${ }^{1}$ \\ 1 Institute of Chemical and Electrochemical Process Engineering, Clausthal University of Technology, \\ 38678 Clausthal-Zellerfeld, Germany; bolong.jiang@tu-clausthal.de (B.J.); kunz@icvt.tu-clausthal.de (U.K.) \\ 2 CUTEC Research Center for Environmental Technologies, 38678 Clausthal-Zellerfeld, Germany; \\ dennis.haupt@cutec.de (D.H.); michael.sievers@cutec.de (M.S.) \\ * Correspondence: thorben.muddemann@tu-clausthal.de \\ + These authors contributed equally to this work.
}

Received: 5 November 2019; Accepted: 17 December 2019; Published: 19 December 2019

\begin{abstract}
This contribution describes the effect of the quality of the catalyst coating of cathodes for wastewater treatment by microbial fuel cells (MFC). The increase in coating quality led to a strong increase in MFC performance in terms of peak power density and long-term stability. This more uniform coating was realized by an airbrush coating method for applying a self-developed polymeric solution containing different catalysts $\left(\mathrm{MnO}_{2}, \mathrm{MoS}_{2}, \mathrm{Co}_{3} \mathrm{O}_{4}\right)$. In addition to the possible automation of the presented coating, this method did not require a calcination step. A cathode coated with catalysts, for instance, $\mathrm{MnO}_{2} / \mathrm{MoS}_{2}$ (weight ratio 2:1), by airbrush method reached a peak and long-term power density of 320 and $200-240 \mathrm{~mW} / \mathrm{m}^{2}$, respectively, in a two-chamber MFC. The long-term performance was approximately three times higher than a cathode with the same catalyst system but coated with the former paintbrush method on a smaller cathode surface area. This extraordinary increase in MFC performance confirmed the high impact of catalyst coating quality, which could be stronger than variations in catalyst concentration and composition, as well as in cathode surface area.
\end{abstract}

Keywords: microbial fuel cell; wastewater treatment; oxygen reduction reaction; municipal wastewater; $\mathrm{MnO}_{2} ; \mathrm{MoS}_{2} ; \mathrm{Co}_{3} \mathrm{O}_{4} ;$ spray method

\section{Introduction}

The permanent rise in standard of living correlates with an increasing energy demand [1]. Particularly in view of global warming and the intended abandonment of fossil and nuclear fuels, processes must be developed that provide environmentally friendly energy [2]. Another challenge is water scarcity, causing 1.2 billion people to suffer from a lack of water and leaving another 1.6 billion people without any access to hygienically safe drinking water [3]. Microbial fuel cells (MFC) are a promising technology that can contribute to a decentralized solution for these future challenges, enabling expansion and assurance of water availability and energy supply $[4,5]$.

Microbial fuel cells (MFCs) combine electrical energy generation with simultaneous wastewater treatment by microorganisms [5]. Anodic exoelectrogenic bacteria oxidize organic compounds from wastewater [6,7]. In combination with a coupled reduction reaction, a positive potential difference, and therefore a net power, is achieved [8]. Oxygen is usually used as final electron acceptor in the coupled oxygen reduction reaction (ORR) at the cathode, as oxygen is available in ambient air [8]. The schematic structure of the investigated MFC is shown in Figure 1. 


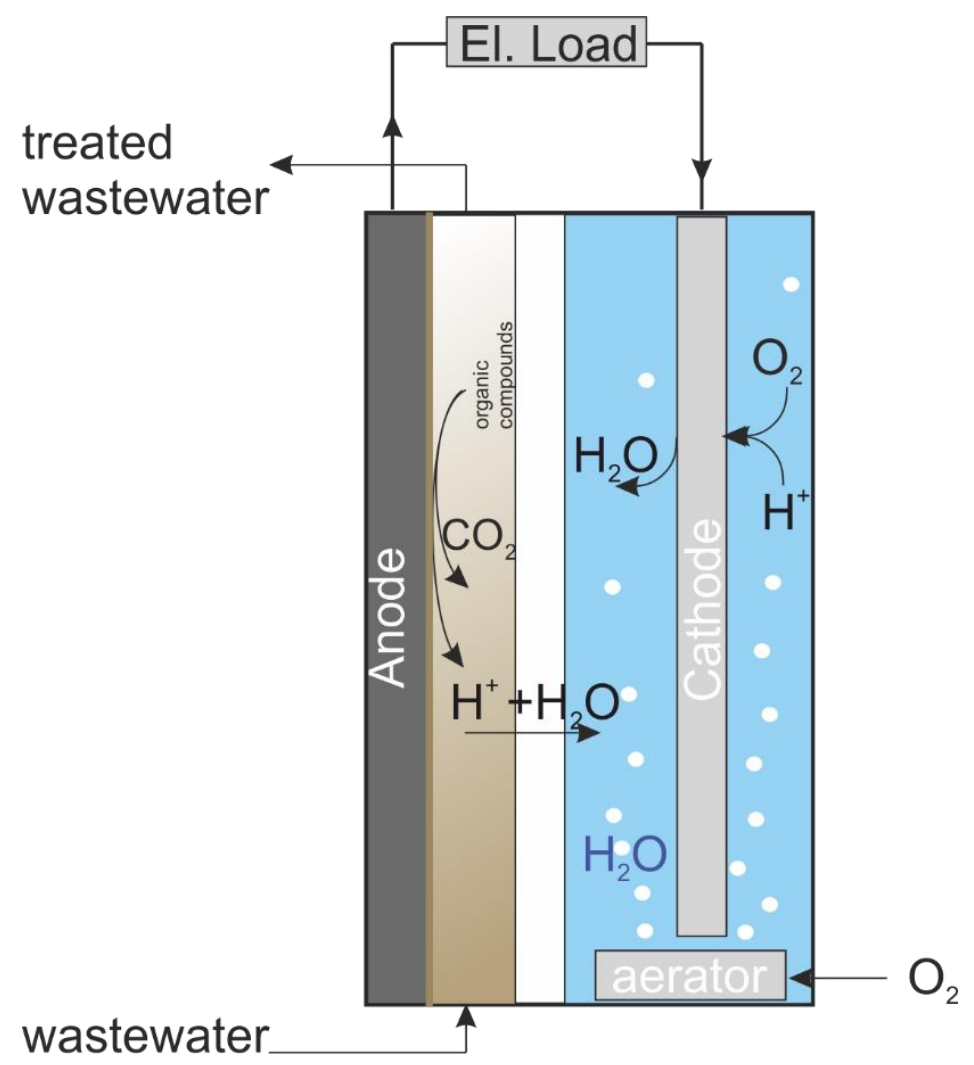

Figure 1. Schematic drawing of the investigated microbial fuel cell (MFC): a planar anode overgrown with bacteria (dark gray), an oxygen-reducing cathode (light gray), and cation exchange membrane (white). The desired reactions and subsequent products are sketched. An electrical load (El. Load) is placed in the outer electrical circuit to use the generated power.

The net power generation of MFCs is rather low, especially due to the performance-limiting cathode [9-12]. To overcome this bottleneck, large electrode surfaces [13], improved cathode manufacturing methods, and especially scalable methods are needed [5]. In the laboratory, cathodes for MFCs are often prepared by brushing [9,14-18], dipping [19], rolling [20], pressing [21], doctor blading [12], spin coating [22], or electro deposition [19,23]. Most of these methods are either not applicable, or less so, for economical technical scale electrodes because they are time-consuming, complex, or not adaptable. Several patents describe manufacturing methods for large-scale cathodes for chemical fuel cells [24-26] or chlor-alkali electrolysis [27,28], but these methods are not yet adapted for MFCs. For that reason, a cathode-coating method is presented in this study, which is also a promising approach for automation, and for the use of large-scale cathodes for MFCs for the first time.

This coating is realized by an airbrush method for applying a self-developed polymeric solution containing catalysts. The coating process was investigated with different catalysts, their different mixing ratios, and different metal meshes.

Next to carbon, $\mathrm{MnO}_{2}, \mathrm{MoS}_{2}$ (with varying mixing ratios), and $\mathrm{Co}_{3} \mathrm{O}_{4}$ (with $\mathrm{TiO}_{2}$ as support material) were investigated as additional catalysts for ORR. As a benchmark for ORR [8], one electrode was coated with $\mathrm{Pt}$ as the catalyst. Unfortunately, $\mathrm{Pt}$ is very expensive and susceptible to catalyst poisoning by $\mathrm{S}_{2}{ }^{-}$or $\mathrm{NH}_{4}{ }^{+}$[29], which are commonly present in municipal wastewater, and as a consequence $\mathrm{Pt}$ is not suitable for wastewater treatment applications.

Several publications investigated $\mathrm{MnO}_{2}$ as an ORR catalyst for MFCs, including the influence of its different modifications (alpha, beta, gamma), different mixing ratios, and varying manufacturing methods. Modifications of $\mathrm{MnO}_{2}$ were studied by Zhang et al. in an MFC (glucose as feed). The maximum power densities differ from $125 \mathrm{~mW} / \mathrm{m}^{2}$ (alpha) to $172 \mathrm{~mW} / \mathrm{m}^{2}$ (beta) and $88 \mathrm{~mW} / \mathrm{m}^{2}$ (gamma) [30]. This approach was followed by Roche et al. with similar performances up to $161 \mathrm{~mW} / \mathrm{m}^{2}$ 
(synthetic wastewater) [31]. Newer studies focus on more complex $\mathrm{MnO}_{2}$-based cathodes. Li et al. studied a manganese oxide catalyst with a cryptomelane-type octahedral molecular sieve structure. This catalyst was additionally doped with $\mathrm{Co}, \mathrm{Cu}$, and $\mathrm{Ce}$. The highest power density was measured for the Co-doped system with $180 \mathrm{~mW} / \mathrm{m}^{2}$ (domestic wastewater, acetate) [16], followed by an optimized system with a continuous flow MFC. The maximum power density was $201 \mathrm{~mW} / \mathrm{m}^{2}$ (wastewater inoculum; acetate as feed) [17]. Recent studies partially increased the performance of $\mathrm{MnO}_{2}$ even further. Zhou et al. investigated the behavior of the combination of polyaniline and $\mathrm{MnO}_{2}$ nanocomposites and reached power densities of $248 \mathrm{~mW} / \mathrm{m}^{2}$ (anaerobic digester sludge inoculum) [32]. Furthermore, nano-scaled systems based on low-cost $\mathrm{MnO}_{2}$ nanowires (on carbon support) achieved a maximum of $180 \mathrm{~mW} / \mathrm{m}^{2}$ (combination of domestic and artificial wastewater) [33]. Farahani et al. investigated another $\mathrm{MnO}_{\mathrm{x}}$-based cathode and found that nitrogen-doped carbon with $\mathrm{MnO}_{\mathrm{x}}$ revealed a peak power density of $467 \mathrm{~mW} / \mathrm{m}^{2}$ (acetate as feed) [34]. However, the described cathode production process is complex and is difficult to scale. A further study with modified $\mathrm{MnO}_{2}$ and induced carbon nanotubes $\left(\mathrm{CNT}\right.$ ) revealed a drastically lower power density of approximately $12 \mathrm{~mW} / \mathrm{m}^{2}$ (calculated with the given volumetric power density of $216 \mathrm{~mW} / \mathrm{m}^{3}$ ) [35].

Jiang et al. investigated the performance of $\mathrm{MnO}_{2}$ and its combination with $\mathrm{MoS}_{2}$ (real wastewater). The best combination of $\mathrm{MnO}_{2}$ and $\mathrm{MoS}_{2}$ revealed peak power densities of up to $165 \mathrm{~mW} / \mathrm{m}^{2}[9,14]$. Another investigated composition within this study was $\mathrm{MoS}_{2}$, which is sparsely described in literature. The combination of $\mathrm{MoS}_{2} / \mathrm{C}$ is considerably less investigated than $\mathrm{MnO}_{\mathrm{x}}$ catalysts. Hao et al. evaluated $\mathrm{N}$-doped $\mathrm{MoS}_{2} / \mathrm{C}$ catalysts and reached high power densities $\left(815 \mathrm{~mW} / \mathrm{m}^{2}\right)$ in a small reactor $(28 \mathrm{~mL})$ with artificial wastewater $\left(\right.$ at $\left.30^{\circ} \mathrm{C}\right)$ due to the beneficial catalyst and the optimized process conditions [20].

In comparison, $\mathrm{Co}_{3} \mathrm{O}_{4} / \mathrm{C}$ cathodes are more often studied. Ge et al. revealed power densities of up to $1500 \mathrm{~mW} / \mathrm{m}^{2}$ in an MFC (artificial wastewater). This was confirmed by Xia et al. with power densities of up to $1540 \mathrm{~mW} / \mathrm{m}^{2}$. The performance of real wastewater with high chemical oxygen demand (COD; 56,500 mg/L) was investigated by Kumar et al. They reached power densities up to $503 \mathrm{~mW} / \mathrm{m}^{2}$ [36]. A following study with flower-like $\mathrm{Co}_{3} \mathrm{O}_{4}$ and lower COD loads (digester sludge and acetate) showed lower maximum power densities of $248 \mathrm{~mW} / \mathrm{m}^{2}$ [15]. Our working group already demonstrated the long-term stability of $\mathrm{MnO}_{2}$ [14], $\mathrm{MoS}_{2}$ [9], and $\mathrm{Co}_{3} \mathrm{O}_{4}$ [37] electrodes. It was shown that $\mathrm{MnO}_{2}, \mathrm{MoS}_{2}$, and $\mathrm{Co}_{3} \mathrm{O}_{4}$ have decent ORR properties and fulfill the requirements of MFC cathodes - they are inexpensive, long-term stable, environmentally friendly [38,39], reduce the overvoltage, and are immune to catalyst poising. Unfortunately, these cathodes were produced by a time-consuming manual paintbrush method. Therefore, a novel spray coating method newly adapted to MFC applications by a dedicated suspension is presented, which is also adaptable to automation processes and scalable electrodes.

\section{Materials and Methods}

\subsection{Experimantal Setup}

To compare and characterize all coated electrodes, a laboratory MFC (self-made) was installed. The test facility consists of eight identical test cells, and an overview is given in Figure 2. Purchased graphite compound anodes were used, made of $86 \%$ graphite and $14 \%$ olefinic polymer binder (Eisenhuth $\mathrm{GmbH}$, Osterode am Harz, Germany). This material allowed the microorganisms to grow on the surface and was also scalable. A low-cost membrane type FKS-PET 130 (Fumatech GmbH, Bietigheim-Bissingen, Germany) was used to separate the anaerobic anode chamber and the aerobic cathode chamber. For more information regarding the cell and anode design, refer to [14]. 


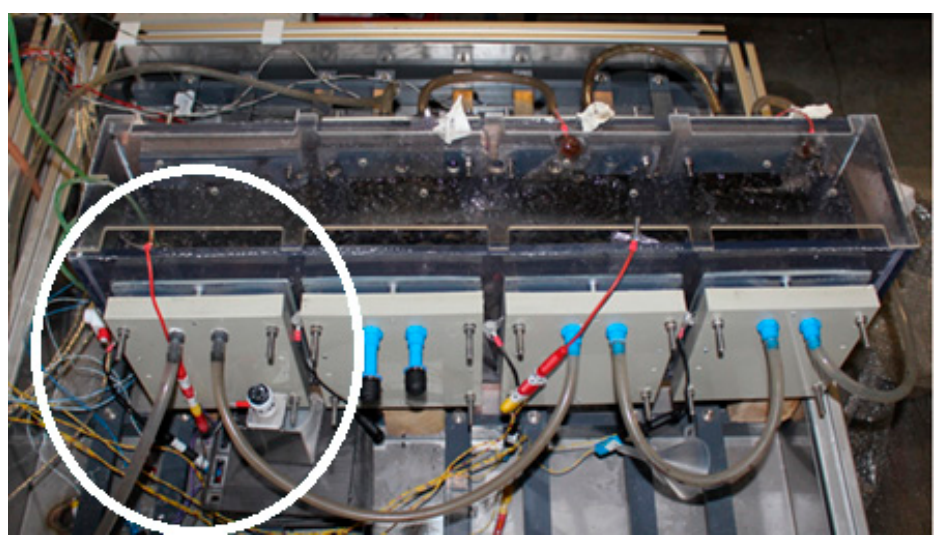

Figure 2. Presentation of the used laboratory system, whereby all measurements were done in the white- marked MFC for comparability.

Each MFC was fed with wastewater via a pump (Pumpen und Anlagentechnik, Lutherstadt Wittenberg, Germany, model: 18ZP-VA 0,68-D30-118 FU) and all cathodes were connected to one water basin aerated with ambient air. For all characterizations, the same test cell (Figure 2, circle) was used to increase the measurements' comparability.

During the operation, the temperature, $\mathrm{pH}$ values, electrical potentials, cell voltage, and current were monitored through a LabView system (National instruments, Austin, TX, USA). All experiments were carried out at a temperature of approximately $16.5{ }^{\circ} \mathrm{C}$ (room temperature in the laboratory). The $\mathrm{pH}$ values were kept at approximately 8 (anolyte) and approximately 10 (catholyte) by adding a sodium carbonate solution ( $20 \mathrm{wt} \%$ ) (Carl Roth GmbH \& Co. KG, Karlsruhe, Germany). A constant current source was used to enable a defined microbial growth at continuously controlled maximum power point conditions. For detailed information about the constant current source, refer to [9,14].

The inoculation process took 2 weeks and was performed with real wastewater taken after the primary clarifier of the sewage treatment plant (STP) Goslar (Eurawasser Betriebsführungsgesellschaft $\mathrm{mbH}$, Goslar, Germany). After filling the anode tank with about $10 \mathrm{~L}$ of wastewater and turning on the pumps, the cells were kept in open circuit for 5 days. Afterwards, each cell was connected to its own constant current source for individual cell operation and regulation.

To evaluate the electrodes under real conditions, the effluent of the primary clarifier from the same STP Goslar with an initial COD of 150 to $200 \mathrm{mg} / \mathrm{L}$ was treated. Despite weekly wastewater exchanges, $10 \mathrm{~mL}$ of a solution of $200 \mathrm{~g} / \mathrm{L}$ glucose (Carl Roth GmbH \& Co. KG, Karlsruhe, Germany). and $200 \mathrm{~g} / \mathrm{L} \mathrm{NaAc}$ (Carl Roth GmbH \& Co. KG, Karlsruhe, Germany) was added daily to keep a constant COD concentration level of approximately $200 \mathrm{mg} / \mathrm{L}$, and to ensure the comparability of results at different dates.

\subsection{Catalysts and Carrier Materials for Cathode}

Printex 6L carbon (Orion Engineered Carbons S.A., Houston, TX, USA) was used for the electrode coating. $\mathrm{MnO}_{2}$ by EMD Millipore Corporation (article number: 805958) (Burlington, MA, USA) and $\mathrm{MoS}_{2}$ by Metallpulver24 Corp. (article number: 22020) (Sakt Augustin, Germany) were used as catalysts. Butanone served as solvent (Sigma-Aldrich, St. Louis, MO, USA, 443468). Due to the high prices of $\mathrm{Co}_{3} \mathrm{O}_{4}$, carrier supported catalysts $\left(\mathrm{Co}_{3} \mathrm{O}_{4} @ \mathrm{TiO}_{2}\right)$ were evaluated. For these $\mathrm{Co}_{3} \mathrm{O}_{4}$ catalysts, $\mathrm{Co}\left(\mathrm{NO}_{3}\right)_{2}$ was obtained by Sigma-Aldrich (article number: 239267) (St. Louis, MO, USA) and anatase $\mathrm{TiO}_{2}$ nano particles by Cofermin Chemical $\mathrm{GmbH}$ (Essen, Germany). Anatase $\mathrm{TiO}_{2}$ in a whiskers morphology was produced according to reference [40]. Fuel cell grade Pt black by De Nora North America ETEK Division (S990670; Painesville, OH, USA) was used for the Pt coating for benchmarking.

Three different types of metal mesh were used as carrier material for the coating. The physical details of the investigated meshes are given in Table 1. Hereinafter, coarse stainless-steel mesh is 
abbreviated as "cSS", fine stainless steel mesh as "fSS", and nickel net with a very fine mesh width as "vfNi".

Table 1. Physical data of the investigated wire meshes for electrode coating.

\begin{tabular}{|c|c|c|c|c|}
\hline Mesh Type & $\operatorname{Mesh}$ Size $\left(\mathrm{mm}^{2}\right)$ & Wire Gauge (mm) & $\begin{array}{c}\text { Surface Area } \\
\left(\mathrm{mm}^{2} \mathrm{~cm}^{-2}\right)\end{array}$ & Manufacturer \\
\hline $\begin{array}{l}\text { Coarse stainless steel } \\
\text { (cSS) }\end{array}$ & $1.8 \times 1.8$ & 0.32 & 94.8 & Spörl KG, Germany \\
\hline $\begin{array}{l}\text { Fine stainless steel } \\
\text { (fSS) }\end{array}$ & $1.0 \times 1.0$ & 0.22 & 116.3 & Spörl KG, Germany \\
\hline $\begin{array}{l}\text { Very fine nickel } \\
\text { (vfNi) }\end{array}$ & $0.106 \times 0.118$ & 0.063 & 627.2 & $\begin{array}{l}\text { Harver \& Böcker, } \\
\text { Germany }\end{array}$ \\
\hline
\end{tabular}

\subsection{Electrode Spray Coating Process}

The coating process for the cathodes is shown in Figure 3. At first, a coating solution has to be prepared, consisting of a basic polymer solution, catalyst, and additional butanone. The basic polymer binder solution was prepared by dissolving three table tennis balls (ink-free with no commercial logos) in $150 \mathrm{~mL}$ butanone to obtain a celluloid solution. Due to the strict standards, table tennis balls form high-quality educts at low prices and fit perfectly to the low-cost approach for a low-cost flexible binder. Then, the basic polymer solution $(20 \mathrm{~mL})$ was merged with additional butanone $(100 \mathrm{~mL})$. To obtain a homogeneous dispersion, the solution was stirred, and the catalysts were added stepwise $(4 \mathrm{~g}$ carbon $+0.4 \mathrm{~g}$ additional catalyst: $\mathrm{MnO}_{2}$ and/or $\left.\mathrm{MoS}_{2}, \mathrm{Co}_{3} \mathrm{O}_{4}\right)$. Then, the mixture was homogenized for $15 \mathrm{~min}$ with a dispersing tool (Heidolph, Germany, model SilentCrusher at 13,500 rpm).

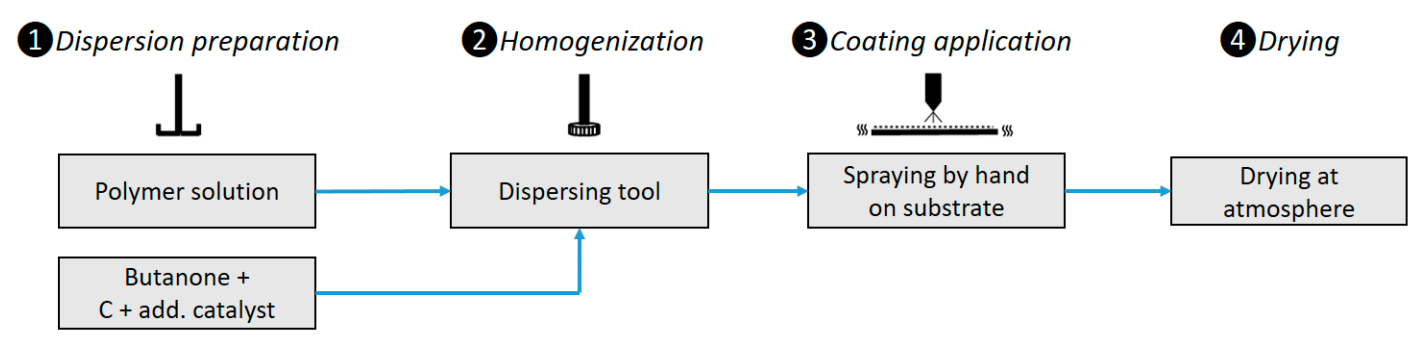

Figure 3. Flow diagram of the process steps for electrode preparation using the spray method.

A spray table with heating option and the degreased (degreaser: isopropanol) metal mesh were heated and controlled at a very stable surface temperature of $110^{\circ} \mathrm{C}$. The dispersion was manually applied with an airbrush spray gun (Harder \& Steenbeck, Norderstedt, Germany, model: Evolution Solo) in cross-coat. Inert nitrogen (Linde Gases Division, Pullach, Germany) was used as carrier gas for spraying ( $3.5 \mathrm{~N}$ grade and a pressure of 2 bar). The applicated mass was controlled by weighting the cathode before, during, and after the coating process. Furthermore, the optimum catalyst loading was evaluated and finally fixed to $0.4 \mathrm{mg} / \mathrm{cm}^{2}$ by preliminary tests. The coating process was completed when the desired catalyst loading was reached. No calcination step was required after coating; therefore, the coating process was timesaving and avoided further changes to the catalyst.

\subsection{Measuring Procedure and Analytical Methods}

A Luggin capillary is usually used to investigate the electrode potential compared with a reference electrode. In order to not only measure the potential at one geometric point, a membrane extension operated as a salt bridge between the cathode and the reference electrode. Therefore, the potentials of the electrodes were measured in an integrative way over the entire active area [41]. The membrane extension was kept moist by an applied carbon fleece in order to stabilize the ionic conductivity and the measurement (Figure 4). A reversible hydrogen electrode (RHE, Gaskatel GmbH, Kassel, Germany) 
served as a reference electrode, which was operated in a buffer solution at $\mathrm{pH} 7$ (Libutec $\mathrm{GmbH}$, Langenfeld, Germany; type: buffer solution $\mathrm{pH}$ 7).

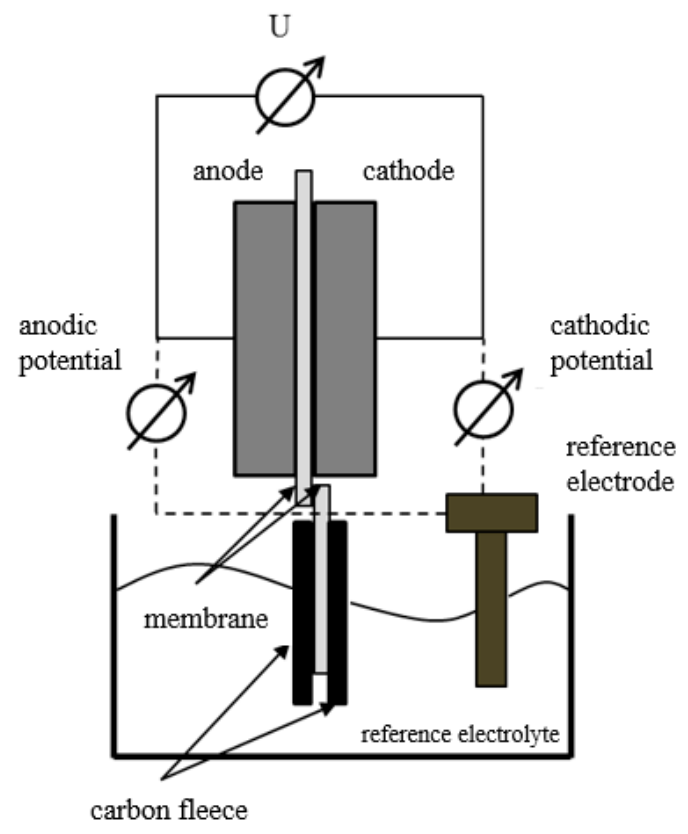

Figure 4. Sketch of the measurement setup and the salt bridge-like membrane extension for potential determination. This modified version is based on [41].

The cathodes were characterized by measuring the electrode potentials and the cell voltages as a function of the current. Furthermore, the power density characteristic curves were calculated and normalized to the geometric area. The power was adjusted between $0 \mathrm{~mA}$ to short circuit current in $1 \mathrm{~mA}$ steps. After each step, the stationary state was awaited (average duration: $5 \mathrm{~min}$ ).

To analyze the chemical composition, an X-ray powder diffraction (XRD) analysis was conducted with a D/max-2200PC-X-ray (Rigaku Corp., The Woodlands, TX, USA) diffractometer (40 kV, $20 \mathrm{~mA})$ using $\mathrm{CuK} \alpha$ radiation $(0.15404 \mathrm{~nm})$ and a scan range between $10^{\circ}$ to $80^{\circ}$, with $10^{\circ} / \mathrm{min}$.

Physical properties were analyzed by the Brunauer-Emmet-Teller (BET) method with a NOVA2000e device (Micromeritics $\mathrm{GmbH}$, Unterschleissheim, Germany) with a prearranged outgassing step at $200{ }^{\circ} \mathrm{C}$ at a vacuum pressure of $6 \mathrm{mmHg}$ of the samples. Selected cathodes were examined with a scanning electron microscope (SEM) at the Institute of Mechanical Process Engineering at Clausthal University of Technology (Carl Zeiss Microscopy GmbH, Jena, Germany, model: DSM 982 Gemini.M).

\section{Results and Discussion}

\subsection{Characterization of Catalysts and Supports}

$\mathrm{MnO}_{2}$ and $\mathrm{MoS}_{2}$ have already been evaluated using XRD and BET; reference is made to [9]. It should be noted that gamma $\mathrm{MnO}_{2}$ was intentionally used, which is significantly cheaper than other modifications. Crystalline phases of the investigated $\mathrm{TiO}_{2}$ supports, and its combination with $\mathrm{Co}_{3} \mathrm{O}_{4}$, are shown in Figure 5. The whiskers type of $\mathrm{TiO}_{2}$ was abbreviated as $\mathrm{TiO}_{2}-\mathrm{W}$, whereas $\mathrm{TiO}_{2}-\mathrm{A}$ is the abbreviation for the anatase modification. The XRD pattern of the supports showed peaks at $2 \theta=$ $25.2^{\circ}, 37.8^{\circ}, 48.0^{\circ}$, and $55.0^{\circ}$, confirming both modifications were anatase phase $\mathrm{TiO}_{2}$. The analysis of the catalyst-loaded $\mathrm{TiO}_{2}$ supports revealed a successful loading, as the peaks of $\mathrm{TiO}_{2}$ were still present, next to the peaks of $\mathrm{Co}_{3} \mathrm{O}_{4}$ at $2 \theta=36.9^{\circ}$ and $65.2^{\circ}$. 

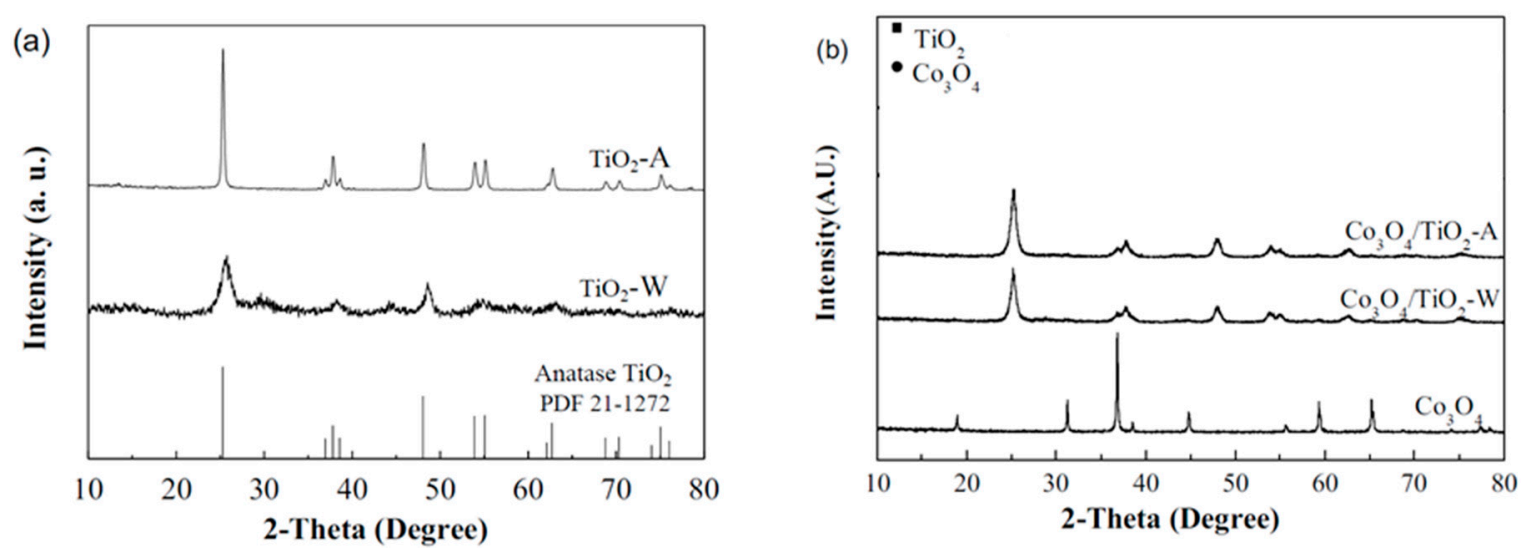

Figure 5. X-ray powder diffraction (XRD) pattern of $\mathrm{TiO}_{2}$ supports (a) and in combination with $\mathrm{Co}_{3} \mathrm{O}_{4}$ catalyst (b).

The BET surface areas of the $\mathrm{TiO}_{2}$-supported and prepared $\mathrm{Co}_{3} \mathrm{O}_{4} / \mathrm{TiO}_{2}$ catalysts are presented in Table 2. The comparison between the investigated $\mathrm{TiO}_{2}$ modifications showed that the $\mathrm{TiO}_{2}-\mathrm{W}$ had a higher specific surface area ( 85.9 to $70 \mathrm{~m}^{2} / \mathrm{g}$ ), and larger pore volume and size. After catalyst loading, the surface area decreased, but the loaded $\mathrm{TiO}_{2}-\mathrm{W}$ support still had a greater surface area.

Table 2. Catalyst content and physical properties of $\mathrm{TiO}_{2}$ carrier and its combination with $\mathrm{Co}_{3} \mathrm{O}_{4}$. $\mathrm{TiO}_{2}$-A: anatase modification of $\mathrm{TiO}_{2}, \mathrm{TiO}_{2}-\mathrm{W}$ : whiskers type of $\mathrm{TiO}_{2}$.

\begin{tabular}{|c|c|c|c|c|}
\hline Sample & $S_{B E T}\left(\mathrm{~m}^{2} \mathrm{~g}^{-1}\right)$ & $V_{P}\left(\mathrm{~cm}^{3} \mathrm{~g}^{-1}\right)$ & $d(\mathrm{~nm})$ & Surface Content (weight \%) \\
\hline $\mathrm{TiO}_{2}-\mathrm{A}$ & 70.0 & 0.241 & 13.5 & - \\
\hline $\mathrm{TiO}_{2}-\mathrm{W}$ & 85.9 & 0.400 & 18.3 & - \\
\hline $\mathrm{Co}_{3} \mathrm{O}_{4} / \mathrm{TiO}_{2}-\mathrm{A}$ & 60.9 & 0.231 & 14.1 & 13.0 \\
\hline $\mathrm{Co}_{3} \mathrm{O}_{4} / \mathrm{TiO}_{2}-\mathrm{W}$ & 77.8 & 0.323 & 15.9 & 4.2 \\
\hline
\end{tabular}

Figure 6 illustrates the Co 2p3/2 spectra of the prepared catalysts. All patterns revealed two peaks at $786.2 \mathrm{eV}$ and $779.4 \mathrm{eV}$, whereas the small peak can be attributed to $\mathrm{Co}^{2+}$ species, and the bigger peak at $779.4 \mathrm{eV}$ to $\mathrm{Co}^{3+}$. Using this reasoning, $\mathrm{Co}_{3} \mathrm{O}_{4}$ was the predominant phase for all samples.

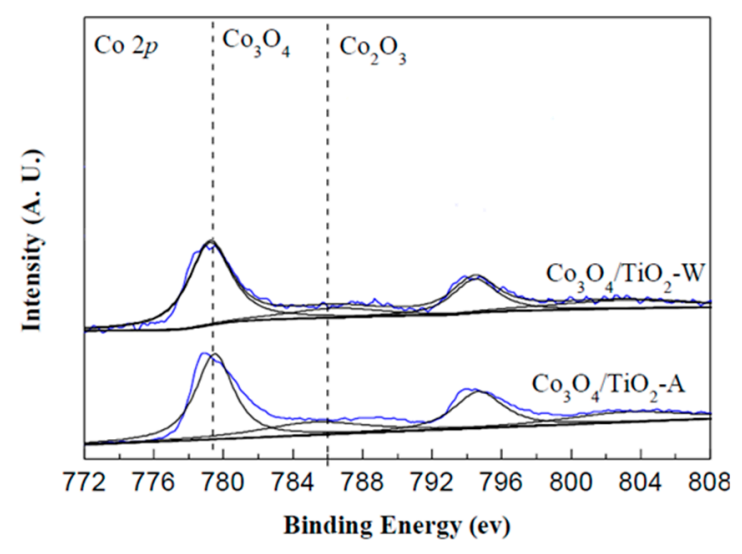

Figure 6. Co 2p3/2 spectra for the supported catalysts. The binding energy for $\mathrm{Co}_{3} \mathrm{O}_{4}(779.4 \mathrm{eV})$ and $\mathrm{Co}_{2} \mathrm{O}_{3}(786.2 \mathrm{eV})$ is shown. 


\subsection{Performance of Coated Electrodes}

\subsubsection{Comparison of $\mathrm{MnO}_{2}, \mathrm{MoS}_{2}$, and $\mathrm{Co}_{3} \mathrm{O}_{4}$-Based Cathodes}

The presented spraying method was applied to a variety of catalysts $\left(\mathrm{MnO}_{2}, \mathrm{MoS}_{2}, \mathrm{Co}_{3} \mathrm{O}_{4}\right.$, and $\left.\mathrm{Pt}\right)$ and different metal meshes. A summary of the fabricated and tested combinations is given in Table 3.

Table 3. Overview of the produced electrodes by the novel spray method on different meshes.

\begin{tabular}{cccc}
\hline Added Catalyst & $\begin{array}{c}\text { Coarse Stainless } \\
\text { Steel Mesh }\end{array}$ & $\begin{array}{c}\text { Fine Stainless } \\
\text { Steel Mesh }\end{array}$ & $\begin{array}{c}\text { Very Fine Ni } \\
\text { Mesh }\end{array}$ \\
\hline $\mathrm{Pt}$ & $\mathrm{x}$ & & \\
$\mathrm{MnO}_{2}$ & $\mathrm{x}$ & $\mathrm{x}$ & $\mathrm{x}$ \\
$\mathrm{MoS}_{2}$ & $\mathrm{x}$ & $\mathrm{x}$ & $\mathrm{x}$ \\
$\mathrm{MnO}_{2}+\mathrm{MoS}_{2}$ with $1: 1$ & $\mathrm{x}$ & $\mathrm{x}$ & $\mathrm{x}$ \\
$\mathrm{MnO}_{2}+\mathrm{MoS}_{2}$ with $1: 2$ & $\mathrm{x}$ & $\mathrm{x}$ & $\mathrm{x}$ \\
$\mathrm{MnO}_{2}+\mathrm{MoS}_{2}$ with $2: 1$ & $\mathrm{x}$ & & \\
$\mathrm{Co}_{3} \mathrm{O}_{4}$ at $\mathrm{TiO}_{2}-\mathrm{A}$ & $\mathrm{x}$ & & \\
$\mathrm{Co}_{3} \mathrm{O}_{4}$ at $\mathrm{TiO}_{2}-\mathrm{W}$ & $\mathrm{x}$ & & \\
\hline
\end{tabular}

In order to achieve a concise comparison of the investigated cathodes, all electrode configurations were characterized as described. Figure 7 shows an example of a power density curve, including the anode and cathode potential curve, as well as the current-voltage curve.

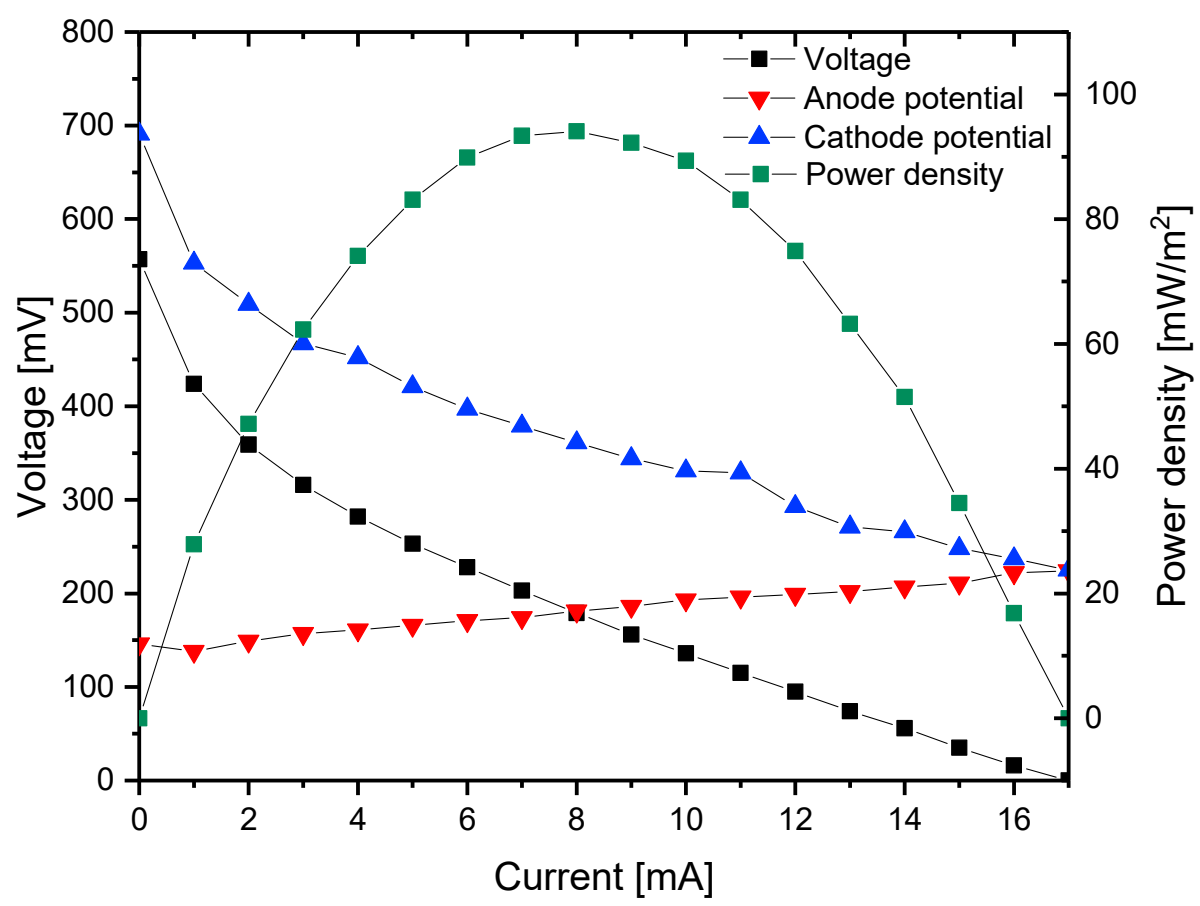

Figure 7. Characteristic curves of an microbial fuel cell (MFC) with a spray-coated cathode based on $\mathrm{MnO}_{2}-\mathrm{MoS}_{2}$ (1:1) on fSS wire mesh. This example also underlines the cathodic bottleneck of the system, determined by the stronger decreasing cathodic potential in comparison to the anodic potential.

The maximum performance of each electrode is given in Figure 8. For the sake of clarity, electrodes with different meshes, but identical catalysts, are presented in clusters. A cathode based on the reference catalyst $\mathrm{Pt}$ (fuel cell grade $\mathrm{Pt}$ at cSS substrate) was produced and used for comparison in Figure 8 (left). 


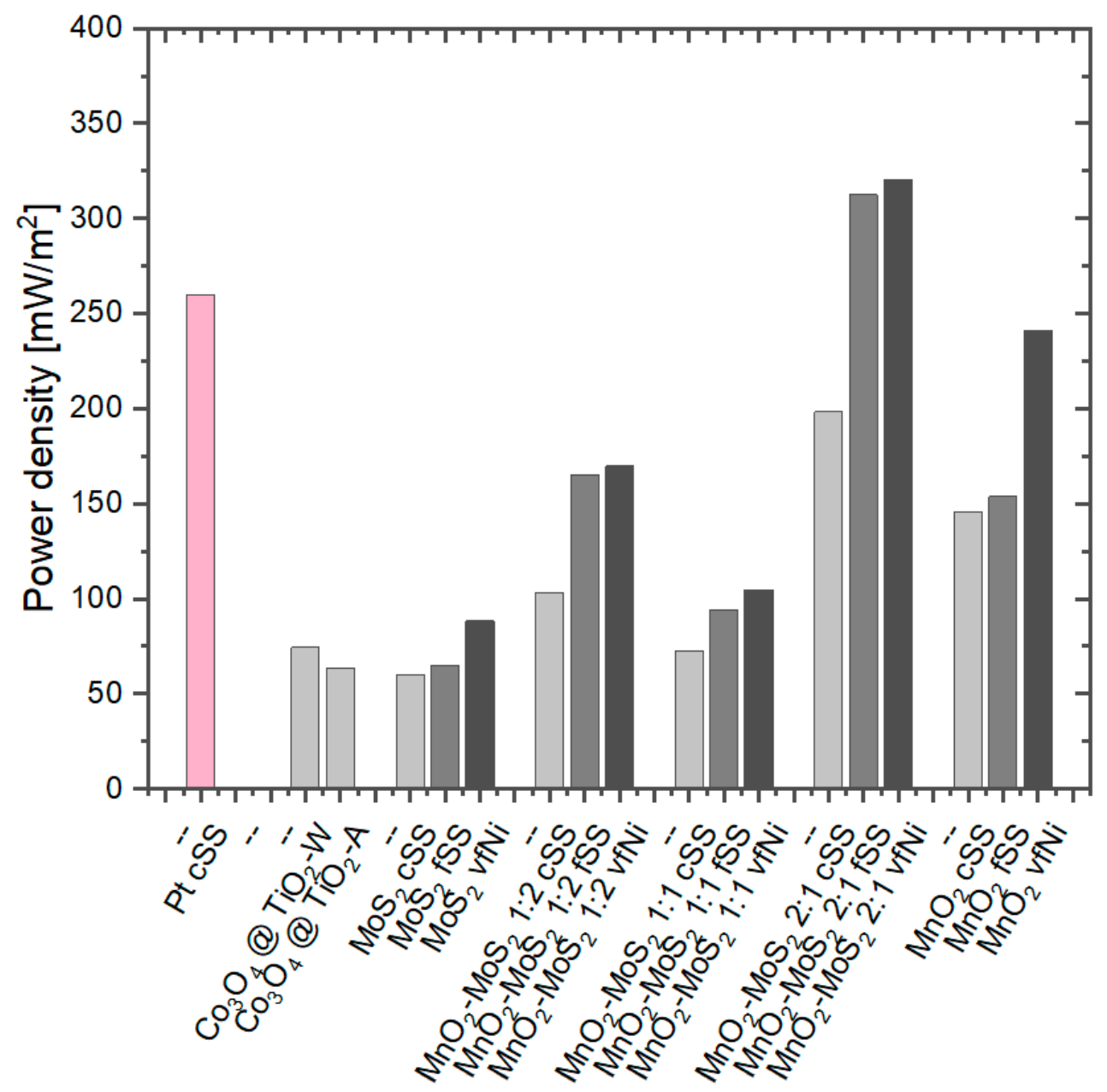

Figure 8. Comparison of maximum power densities of different cathodes. All electrodes were manufactured with a catalyst load of $0.4 \mathrm{mg} / \mathrm{cm}^{2}$.

The comparison clearly indicates that all catalysts benefit from an increasing surface area of the metal meshes. The performance increases from coarse (cSS) to fine stainless-steel mesh (fSS) and is outperformed by the cathodes on very fine nickel mesh (vfNi). However, the 5.4-times increase of surface area of vfNi mesh cathode compared to fSS mesh cathodes only led to a slight increase in MFC performance for different catalyst systems, including the best one $\left(\mathrm{MnO}_{2}-\mathrm{MoS}_{2} 2: 1\right)$. For the $\mathrm{MnO}_{2}$ catalyst, a significant increase of approximately $80 \mathrm{~mW} / \mathrm{m}^{2}(30 \%)$ was found, but still at a lower level than the best catalyst system. These results indicate an existing limit for the impact of electrode surface area on the improvement of MFC performance.

Electrodes with $\mathrm{CO}_{3} \mathrm{O}_{4}$ (on $\mathrm{TiO}_{2}$ support) and $\mathrm{MoS}_{2}$ showed the lowest power density (only $60-88 \mathrm{~mW} / \mathrm{m}^{2}$ ). Both investigated $\mathrm{Co}_{3} \mathrm{O}_{4}$ on $\mathrm{TiO}_{2}$ systems (in combination with carbon and polymer) showed similar results, but the $\mathrm{Co}_{3} \mathrm{O}_{4} / \mathrm{TiO}_{2}-\mathrm{W}$ cathode was slightly better $\left(74.4 \mathrm{~mW} / \mathrm{m}^{2}\right)$ in comparison to $\mathrm{Co}_{3} \mathrm{O}_{4} / \mathrm{TiO}_{2}-\mathrm{A}\left(63.6 \mathrm{~mW} / \mathrm{m}^{2}\right)$, probably caused by the increased surface area.

The increasing surface area caused by the finer mesh width also had a positive effect on $\mathrm{MoS}_{2}$-based cathodes, but the performance was still low $\left(60.2,65.1\right.$, and $\left.88.5 \mathrm{~mW} / \mathrm{m}^{2}\right)$. The oxygen reduction capability of $\mathrm{MnO}_{2}$ was considerably higher. The increase from cSS to fSS enhanced the maximum power density from 145.4 to $153.9 \mathrm{~mW} / \mathrm{m}^{2}$. A further improvement was given by the usage of the vfNi mesh, showing power densities up to $240.9 \mathrm{~mW} / \mathrm{m}^{2}$. Sulphur compounds in wastewater are known as catalyst poisons, and it was recently shown that a catalyst combination with $\mathrm{MoS}_{2}$ increases the long-term stability of MFC cathode catalysts [9]. Therefore, different mixing ratios were investigated. 
The (weight \%) mixing ratio of 1:1 $\left(\mathrm{MnO}_{2}-\mathrm{MoS}_{2}\right)$ led to a performance deterioration compared to the pure $\mathrm{MnO}_{2}$ system, and the electrodes showed similar performances to the $\mathrm{MoS}_{2}$ cathodes on all substrates. The mixing ratios of 1:2 and 2:1 performed differently, but they showed an improving effect. In particular, the electrodes with a mixing ratio of 2:1 showed power densities of $198.3 \mathrm{~mW} / \mathrm{m}^{2}$ $\left(\mathrm{MnO}_{2}-\mathrm{MoS}_{2} 2: 1, \mathrm{cSS}\right), 312.3 \mathrm{~mW} / \mathrm{m}^{2}\left(\mathrm{MnO}_{2}-\mathrm{MoS}_{2} 2: 1, \mathrm{fSS}\right)$, and $320.6 \mathrm{~mW} / \mathrm{m}^{2}\left(\mathrm{MnO}_{2}-\mathrm{MoS}_{2} 2: 1, \mathrm{vfNi}\right)$. An even better performance was reached with the fSS and vfNi meshes than for the Pt-coated cathode. Potential/current curves of selected cathodes are shown in Figure 9. The diagram clearly indicates the most stable cathode potential curve for $\mathrm{MnO}_{2} / \mathrm{MoS}_{2}$ (2:1). Furthermore, the cathode potential stabilized in terms of current stability from the cSS mesh (grey curve) over the fSS mesh (blue curve) to the vfNi mesh (green curve), with simultaneously increasing cathode surface area. All cathodes showed a potential drop, especially at higher currents. This was probably caused by mass transport limitations.

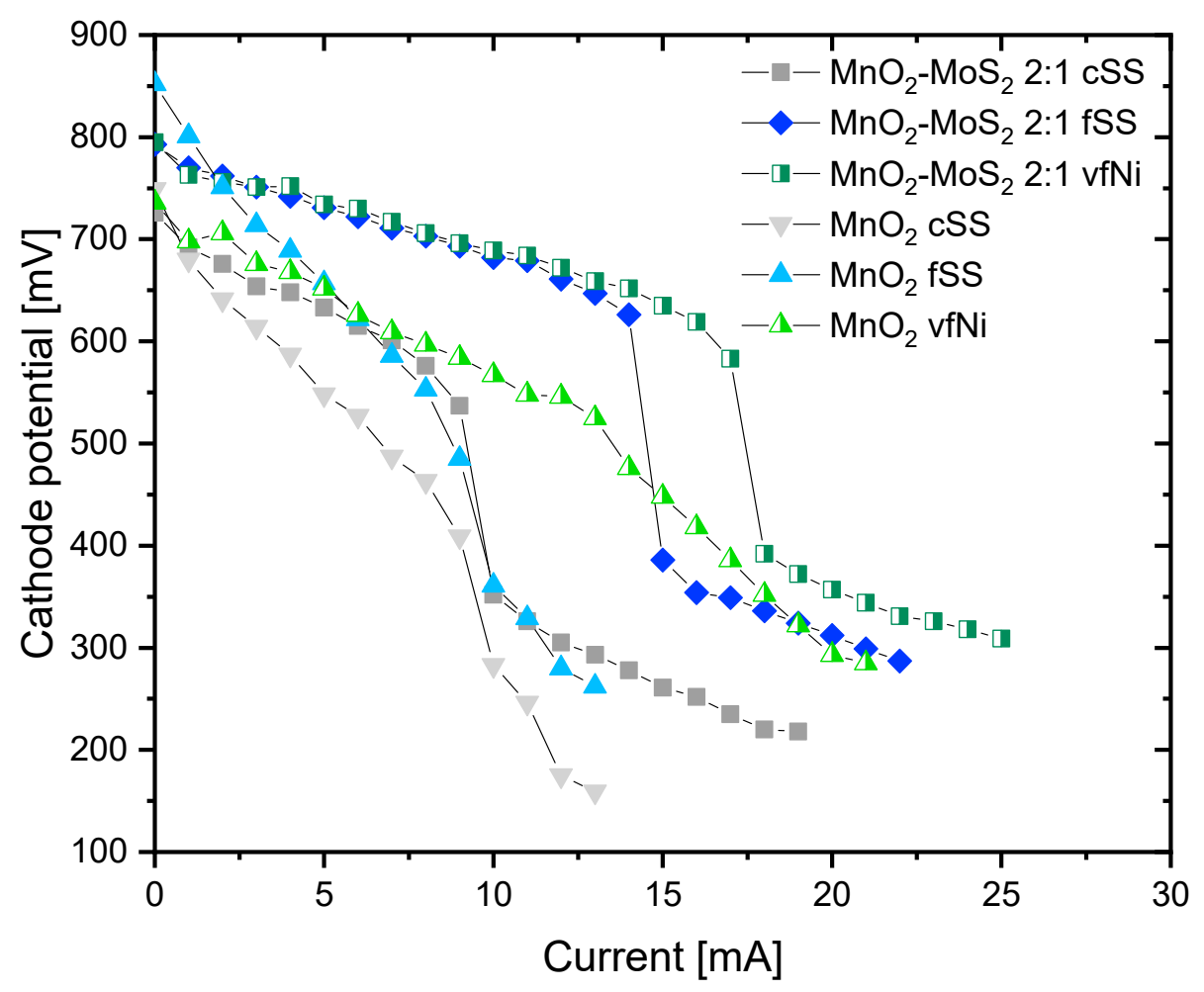

Figure 9. Cathode potentials of selected spray-coated cathodes on different substrates.

Due to the high costs for $\mathrm{Co}_{3} \mathrm{O}_{4}$, carrier-supported catalysts $\left(\mathrm{Co}_{3} \mathrm{O}_{4}\right.$ at $\left.\mathrm{TiO}_{2}\right)$ were evaluated. However, these showed low ORR activity and the achieved currents were below published levels. Obviously, pure $\mathrm{Co}_{3} \mathrm{O}_{4}$ is expected to show significantly better performance, but this is not suitable for wastewater treatment by MFC due to the low cost-efficiency. In conclusion, the $\mathrm{MnO}_{2}$-based cathodes showed significantly better performances. Especially a combination with $\mathrm{MoS}_{2}$ could surpass the performances related to scalable systems described in the literature to date.

\subsubsection{Comparison to Paintbrush-Manufactured Cathodes}

Novel spray coated cathodes were compared to cathodes previously produced by the paintbrush method [9] by SEM. All cathodes had a catalyst ratio of 2:1 $\left(\mathrm{MnO}_{2} / \mathrm{MoS}_{2}\right)$. According to Figure 10, the paintbrush process produced a tight fit between the interstitial spaces, whereby some were closed, whereas other interstitial spaces remained empty. The coating was not uniform and showed a tendency for detaching. The application consisted mainly of elongated particles attached to each other in a porous structure, which were fixed in position by form closure. 



Figure 10. Scanning electron microscope (SEM) image of a cathode produced by paintbrush method with a catalyst ratio of 2:1 $\left(\mathrm{MnO}_{2} / \mathrm{MoS}_{2}\right)$ in different scales.

In contrast, the cathodes produced by the spray coating method showed a more regular coating on the surface of the wire mesh. The finer the wire mesh, the more uniform the distribution. The SEM image of coated vfNi substrate is shown as an example in Figure 11.
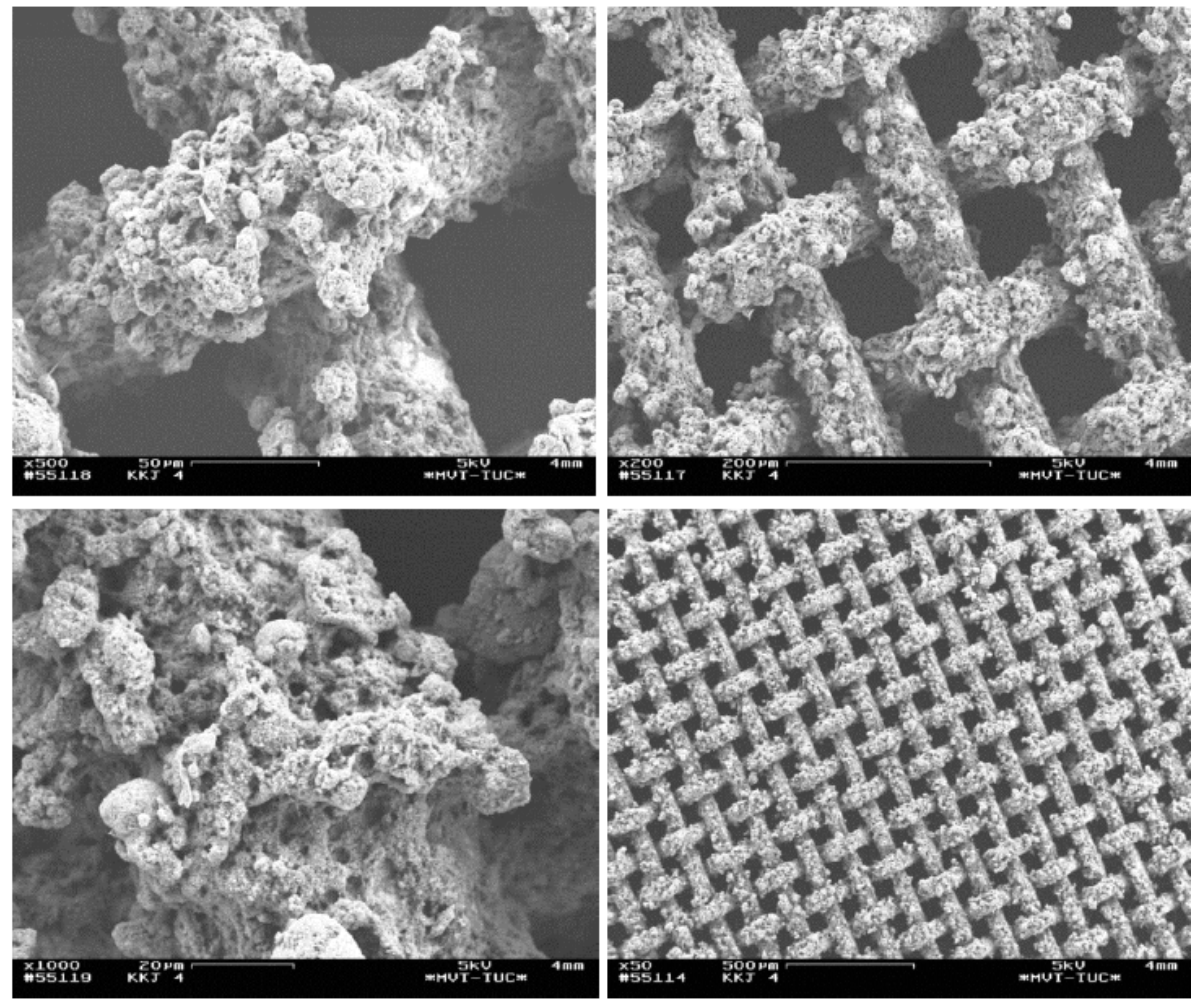

Figure 11. SEM image of a spray coated cathode with a catalyst ratio of 2:1 $\left(\mathrm{MnO}_{2} / \mathrm{MoS}_{2}\right)$ in different scales. 
Thus, it was shown that the presented spray method enabled uniform and reproducible catalytic coatings. The developed spray coating method seems to be a promising process for the production of high-performance electrodes and also for upscaling. The method also enabled a suitable comparison between different catalysts through homogenous coatings. No additional calcination steps were necessary, which could modify the catalyst structure.

\subsubsection{Long-Term Performance of Selected Electrodes}

The long-term performance of the best performing spray-coated cathode $\left(\mathrm{MnO}_{2}-\mathrm{MoS}_{2} 2: 1 \mathrm{vfNi}\right)$ in comparison to a paintbrush-coated cathode (according to [9]) is given in Figure 12. It was noted that the paintbrush method was applied on a cSS net, as the paintbrush method would cause clogging on finer mesh width. Although a drop in power density was noticeable at the beginning of the measurement, a relatively constant power density of $150 \mathrm{~mW} / \mathrm{m}^{2}$ was reached from the fourth day onwards. From day 6 , the power density rose, reaching $200-240 \mathrm{~mW} / \mathrm{m}^{2}$ from day 10 onwards. The long-term performance of paintbrush-coated electrode was about 60 to $100 \mathrm{~mW} / \mathrm{m}^{2}$. The comparison of the long-term performance between both electrodes by different coating methods revealed a performance improvement by factor 2 to 3 , or in terms of power density, by 100 to $180 \mathrm{~mW} / \mathrm{m}^{2}$ for the spray-coated cathode. The comparison between the improvement of long-term power density and the improvement of maximum power density showed that the improvement in long-term performance was higher than that in maximum performance. Therefore, the spray-coating method was identified as enabling the production of high-performing and long-term stable cathodes for MFC application.

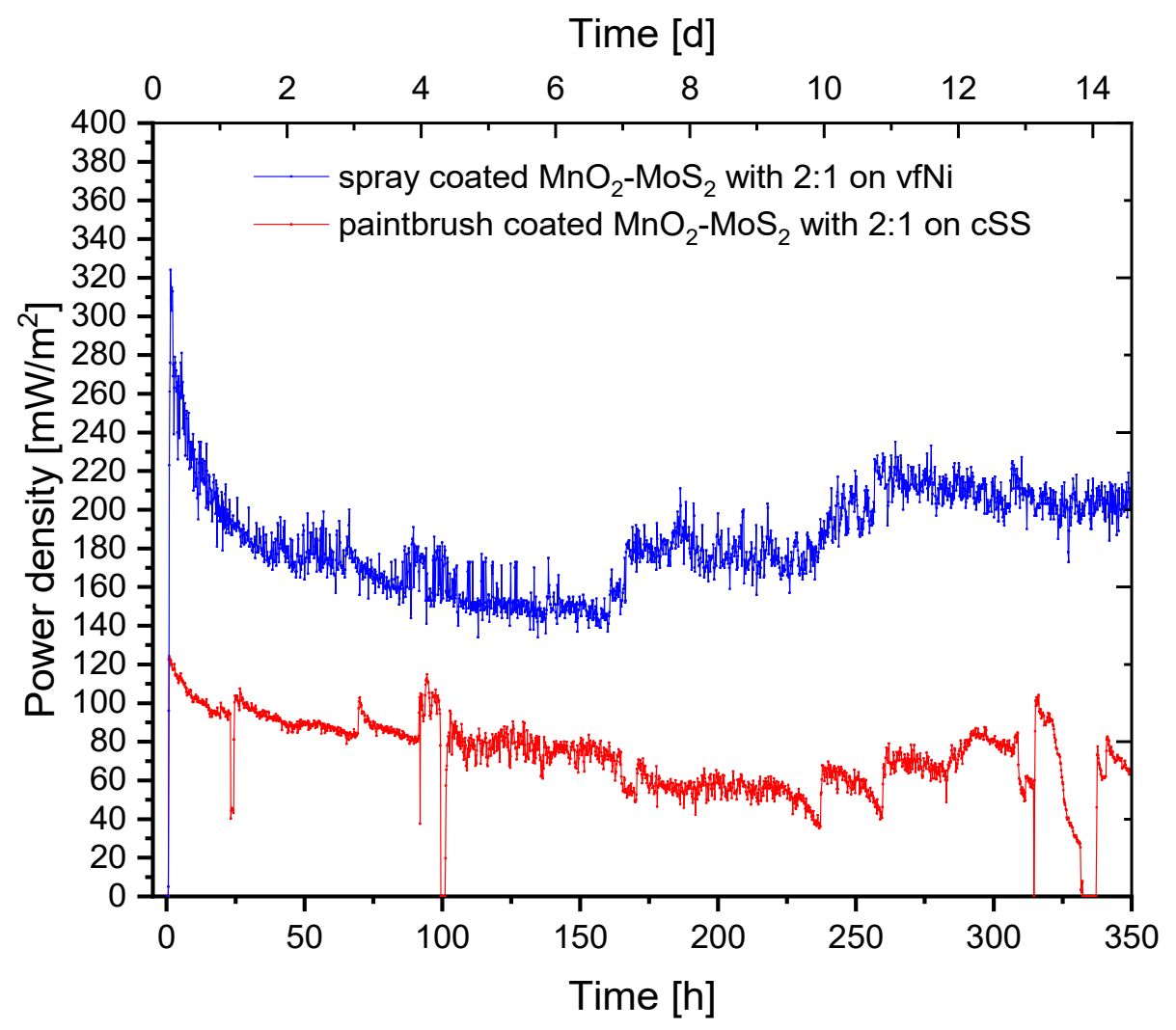

Figure 12. Long-term performance of the spray-coated $\mathrm{MnO}_{2}-\mathrm{MoS}_{2}(2: 1)$ vfNi cathode.

\section{Conclusions}

To scale-up MFCs to the dimensions of technical-scale wastewater treatment plants, it is necessary to manufacture scalable electrodes. Therefore, the composition of a universal sprayable suspension was developed within this study, which was used for a simplified airbrush spray-coating method. The performance was evaluated regarding different catalysts $\left(\mathrm{Co}_{3} \mathrm{O}_{4}, \mathrm{MnO}_{2}, \mathrm{MoS}_{2}\right.$, and selected 
combinations) on different carrier meshes and materials. The spray-coating method facilitated a homogeneous coating and stood out with an increased cathode performance. This could be enhanced further by suitable substrates with a finer mesh width and a higher surface area. The most promising cathode catalyst composition of the tested systems was the combination of $\mathrm{MnO}_{2}$ and $\mathrm{MoS}_{2}$ mixture (2:1) with a maximum and long-term power density of 320 and $200-240 \mathrm{~mW} / \mathrm{m}^{2}$, respectively. The coated electrodes also demonstrated long-term stability. This contribution confirmed the effect of the quality of the catalyst coating of cathodes for wastewater treatment by microbial fuel cells (MFC). A promising and more rapid manufacturing method for better catalyst comparisons and large-scale applications was identified. This process could also be the basis for an automated coating. Moreover, this work demonstrated that not only the catalytic components and their composition influenced electrocatalytic properties. The method of preparation and the carrier mesh also exerted a large effect on the electrode performance.

Author Contributions: Conceptualization, methodology, validation, data curation, visualization, writingoriginal draft preparation, T.M. and D.H.; investigation, T.M., D.H., and B.J.; writing-review and editing, all authors; supervision, project administration, funding acquisition, M.S. and U.K. All authors have read and agreed to the published version of the manuscript.

Funding: This research was funded by the Federal Ministry of Education and Research (Bundesministerium für Bildung und Forschung), BMBF, Germany, grant number WTER0219813.

Conflicts of Interest: The authors declare no conflict of interest.

\section{References}

1. Muddemann, T.; Haupt, D.; Sievers, M.; Kunz, U. Electrochemical Reactors for Wastewater Treatment. ChemBioEng Rev. 2019, 6, 142-156. [CrossRef]

2. United Nations. The Millennium Development Goals Report; United Nations: New York, NY, USA, 2006.

3. UN Water and FAO. Coping with Water Scarcity - Challenge of the Twenty-First Century; UN Water and FAO: Rome, Italy, 2007.

4. Logan, B.E. Microbial Fuel Cells; John Wiley \& Sons, Inc.: Hoboken, NJ, USA, 2008; ISBN 978-0-470-23948-3.

5. Hernández-Fernández, F.J.; Pérez de los Ríos, A.; Salar-García, M.J.; Ortiz-Martínez, V.M.; Lozano-Blanco, L.J.; Godínez, C.; Tomás-Alonso, F.; Quesada-Medina, J. Recent progress and perspectives in microbial fuel cells for bioenergy generation and wastewater treatment. Fuel Process. Technol. 2015, 138, 284-297. [CrossRef]

6. Zhang, X.; He, W.; Ren, L.; Stager, J.; Evans, P.J.; Logan, B.E. COD removal characteristics in air-cathode microbial fuel cells. Bioresour. Technol. 2015, 176, 23-31. [CrossRef] [PubMed]

7. Malvankar, N.S.; Lovley, D.R. Microbial nanowires: A new paradigm for biological electron transfer and bioelectronics. ChemSusChem 2012, 5, 1039-1046. [CrossRef] [PubMed]

8. Yuan, H.; Hou, Y.; Abu-Reesh, I.M.; Chen, J.; He, Z. Oxygen reduction reaction catalysts used in microbial fuel cells for energy-efficient wastewater treatment: A review. Mater. Horiz. 2016, 3, 382-401. [CrossRef]

9. Jiang, B.; Muddemann, T.; Kunz, U.; Silva e Silva, L.G.; Bormann, H.; Niedermeiser, M.; Haupt, D.; Schläfer, O.; Sievers, M. Graphite/ $\mathrm{MnO}_{2}$ and $\mathrm{MoS}_{2}$ Composites Used as Catalysts in the Oxygen Reduction Cathode of Microbial Fuel Cells. J. Electrochem. Soc. 2017, 164, E519-E524. [CrossRef]

10. Rahimnejad, M.; Adhami, A.; Darvari, S.; Zirepour, A.; Oh, S.-E. Microbial fuel cell as new technology for bioelectricity generation: A review. Alex. Eng. J. 2015, 54, 745-756. [CrossRef]

11. Rismani-Yazdi, H.; Carver, S.M.; Christy, A.D.; Tuovinen, O.H. Cathodic limitations in microbial fuel cells: An overview. J. Power Sources 2008, 180, 683-694. [CrossRef]

12. Santoro, C.; Arbizzani, C.; Erable, B.; Ieropoulos, I. Microbial fuel cells: From fundamentals to applications. A review. J. Power Sources 2017, 356, 225-244. [CrossRef]

13. Muddemann, T.; Haupt, D.R.; Gomes Silva e Silva, L.; Jiang, B.; Kunz, U.; Bormann, H.; Niedermeiser, M.; Schlaefer, O.; Sievers, M. Integration of Upscaled Microbial Fuel Cells in Real Municipal Sewage Plants. ECS Trans. 2017, 77, 1053-1077. [CrossRef]

14. Jiang, B.; Muddemann, T.; Kunz, U.; Bormann, H.; Niedermeiser, M.; Haupt, D.; Schläfer, O.; Sievers, M. Evaluation of Microbial Fuel Cells with Graphite Plus $\mathrm{MnO}_{2}$ and $\mathrm{MoS}_{2}$ Paints as Oxygen Reduction Cathode Catalyst. J. Electrochem. Soc. 2016, 164, H3083-H3090. [CrossRef] 
15. Kumar, R.; Singh, L.; Zularisam, A.W. Enhanced oxygen reduction reaction in air-cathode microbial fuel cells using flower-like $\mathrm{Co}_{3} \mathrm{O}_{4}$ as an efficient cathode catalyst. Int. J. Hydrog. Energy 2017, 42, 19287-19295. [CrossRef]

16. Li, X.; Hu, B.; Suib, S.; Lei, Y.; Li, B. Manganese dioxide as a new cathode catalyst in microbial fuel cells. J. Power Sources 2010, 195, 2586-2591. [CrossRef]

17. Li, X.; Hu, B.; Suib, S.; Lei, Y.; Li, B. Electricity generation in continuous flow microbial fuel cells (MFCs) with manganese dioxide $\left(\mathrm{MnO}_{2}\right)$ cathodes. Biochem. Eng. J. 2011, 54, 10-15. [CrossRef]

18. Nandy, A.; Sharma, M.; Venkatesan, S.; Taylor, N.; Gieg, L.; Thangadurai, V. Comparative Evaluation of Coated and Non-Coated Carbon Electrodes in a Microbial Fuel Cell for Treatment of Municipal Sludge. Energies 2019, 12, 1034. [CrossRef]

19. Zhang, Y.; Liu, L.; van der Bruggen, B.; Yang, F. Nanocarbon based composite electrodes and their application in microbial fuel cells. J. Mater. Chem. A 2017, 5, 12673-12698. [CrossRef]

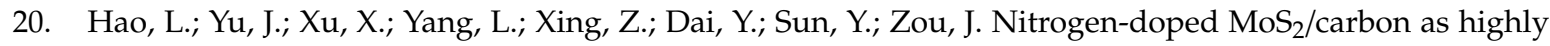
oxygen-permeable and stable catalysts for oxygen reduction reaction in microbial fuel cells. J. Power Sources 2017, 339, 68-79. [CrossRef]

21. Kodali, M.; Santoro, C.; Serov, A.; Kabir, S.; Artyushkova, K.; Matanovic, I.; Atanassov, P. Air Breathing Cathodes for Microbial Fuel Cell using Mn-, Fe-, Co- and Ni-containing Platinum Group Metal-free Catalysts. Electrochim. Acta 2017, 231, 115-124. [CrossRef]

22. Tsai, H.-Y.; Hsu, W.-H.; Liao, Y.-J. Effect of Electrode Coating with Graphene Suspension on Power Generation of Microbial Fuel Cells. Coatings 2018, 8, 243. [CrossRef]

23. Satar, I.; Daud, W.R.W.; Kim, B.H.; Somalu, M.R.; Ghasemi, M.; Bakar, M.H.A.; Jafary, T.; Timmiati, S.N. Performance of titanium-nickel (Ti/Ni) and graphite felt-nickel (GF/Ni) electrodeposited by Ni as alternative cathodes for microbial fuel cells. J. Taiwan Inst. Chem. Eng. 2018, 89, 67-76. [CrossRef]

24. Hideki, M. Manufacturing Equipment and Manufacturing Method of Membrane Electrode Assembly. US20100051181A1, 4 March 2010.

25. Kwon, N.H.; Hwang, I.C.; Ahn, B.K.; Lim, T.W. Method and Apparatus for Preparing Catalyst Slurry for Fuel Cells. US20100086450A1, 8 April 2010.

26. Tochigi, T.T.; Tochigi, S.T.; Tochigi, K.Y. Verfahren zur Herstellung einer Elektrodenschicht für eine Brennstoffzelle. DE1020006046373A1, 5 April 2007.

27. Bulan, A. Sauerstoffverzehrelektrode und Verfahren zu ihrer Herstellung. DE102010024053A1, 22 December 2011.

28. Kintrup, J.; Bulan, A.; Hammarberg, E.; Sepeur, S.; Frenzer, G.; Gross, F. Beschichtungsmischung Herstellung Covestro. US2017067172A1, 9 March 2017.

29. Yang, W.; Li, J.; Lan, L.; Fu, Q.; Zhang, L.; Zhu, X.; Liao, Q. Poison tolerance of non-precious catalyst towards oxygen reduction reaction. Int. J. Hydrog. Energy 2018, 43, 8474-8479. [CrossRef]

30. Zhang, L.; Liu, C.; Zhuang, L.; Li, W.; Zhou, S.; Zhang, J. Manganese dioxide as an alternative cathodic catalyst to platinum in microbial fuel cells. Biosens. Bioelectron. 2009, 24, 2825-2829. [CrossRef] [PubMed]

31. Roche, I.; Katuri, K.; Scott, K. A microbial fuel cell using manganese oxide oxygen reduction catalysts. J. Appl. Electrochem. 2010, 40, 13-21. [CrossRef]

32. Zhou, X.; Xu, Y.; Mei, X.; Du, N.; Jv, R.; Hu, Z.; Chen, S. Polyaniline/ $\beta-\mathrm{MnO}_{2}$ nanocomposites as cathode electrocatalyst for oxygen reduction reaction in microbial fuel cells. Chemosphere 2018, 198, 482-491. [CrossRef]

33. Majidi, M.R.; Shahbazi Farahani, F.; Hosseini, M.; Ahadzadeh, I. Low-cost nanowired $\alpha-\mathrm{MnO}_{2} / \mathrm{C}$ as an ORR catalyst in air-cathode microbial fuel cell. Bioelectrochemistry 2018, 125, 38-45. [CrossRef]

34. Shahbazi Farahani, F.; Mecheri, B.; Reza Majidi, M.; Costa de Oliveira, M.A.; D’Epifanio, A.; Zurlo, F.; Placidi, E.; Arciprete, F.; Licoccia, S. $\mathrm{MnO}_{\mathrm{x}}$-based electrocatalysts for enhanced oxygen reduction in microbial fuel cell air cathodes. J. Power Sources 2018, 390, 45-53. [CrossRef]

35. Woon, C.W.; Ong, H.R.; Chong, K.F.; Chan, K.M.; Khan, M.M.R. $\mathrm{MnO}_{2} / \mathrm{CNT}$ as ORR Electrocatalyst in Air-Cathode Microbial Fuel Cells. Procedia Chem. 2015, 16, 640-647. [CrossRef]

36. Kumar, R.; Singh, L.; Zularisam, A.W.; Hai, F.I. Potential of porous $\mathrm{Co}_{3} \mathrm{O}_{4}$ nanorods as cathode catalyst for oxygen reduction reaction in microbial fuel cells. Bioresour. Technol. 2016, 220, 537-542. [CrossRef]

37. Jiang, B. Optimization of Cathode Performance of Microbial Fuel Cells for Wastewater Treatment and Electrochemical Power Evaluation. Ph.D. Thesis, Clausthal University of Technology, Clausthal-Zellerfeld, Germany, 2018. 
38. Rossi, R.; Jones, D.; Myung, J.; Zikmund, E.; Yang, W.; Gallego, Y.A.; Pant, D.; Evans, P.J.; Page, M.A.; Cropek, D.M.; et al. Evaluating a multi-panel air cathode through electrochemical and biotic tests. Water Res. 2018, 148, 51-59. [CrossRef]

39. Brown, R.K.; Harnisch, F.; Wirth, S.; Wahlandt, H.; Dockhorn, T.; Dichtl, N.; Schröder, U. Evaluating the effects of scaling up on the performance of bioelectrochemical systems using a technical scale microbial electrolysis cell. Bioresour. Technol. 2014, 163, 206-213. [CrossRef]

40. Chen, S.; Zhu, Y.; Li, W.; Liu, W.; Li, L.; Yang, Z.; Liu, C.; Yao, W.; Lu, X.; Feng, X. Synthesis, Features, and Applications of Mesoporous Titania with $\mathrm{TiO}_{2}$ (B). Chin. J. Catal. 2010, 31, 605-614. [CrossRef]

41. He, W.; van Nguyen, T. Edge Effects on Reference Electrode Measurements in PEM Fuel Cells. J. Electrochem. Soc. 2004, 151, A185. [CrossRef]

(C) 2019 by the authors. Licensee MDPI, Basel, Switzerland. This article is an open access article distributed under the terms and conditions of the Creative Commons Attribution (CC BY) license (http://creativecommons.org/licenses/by/4.0/). 